\title{
FAKTOR-FAKTOR YANG MEMPENGARUHI KEPATUHAN PROTOKOL KESEHATAN PADA MASA TATANAN BARU DI BANDAR LAMPUNG
}

\author{
Prihantoro $^{1^{*}}$, Lolita Sary ${ }^{2}$, Fitri Ekasari ${ }^{3}$, Khoidar Amirus ${ }^{4}$ \\ ${ }^{1-4}$ Universitas Malahayati, Lampung, Indonesia \\ Email Korespondensi: aand.hse@gmail.com \\ Disubmit: 24 Januari 2022 Diterima: 31 Januari 2022 Diterbitkan: 02 Februari 2022 \\ DOI: https://doi.org/10.33024/mnj.v5i2.5873
}

\section{ABSTRACT: FACTORS AFFECTING HEALTH PROTOCOL COMPLIANCE WHEN NEW ORDER IN BANDAR LAMPUNG}

Introduction: The Covid-19 pandemic shows cases that continue to increase, especially in the Sukarame District area. But on the other hand, public awareness in implementing health protocols is still low.

Objective: The purpose of this study was to determine the factors that influence compliance with health protocols during the New Order era in Sukarame District, Bandar Lampung City in 2021.

Methods: This type of research is quantitative, with a cross sectional design. The research was conducted in Sukarame District, Bandar Lampung City. The number of population and sample was determined based on accidental sampling so that the sample obtained in this study amounted to 97 respondents. The data analysis techniques used were univariate, bivariate (chi-square), and multivariate (multiple logistic regression). Results: The results showed that there was an effect of perceived vulnerability ( $p v=0.001)$, perceived severity $(p v=0.022)$, perceived barriers $(p v=0.034)$, and perceived benefits $(p v=0.018)$ on adherence to health protocols during the New Order in the District. Sukarame City of Bandar Lampung.

Conclusion: This study suggests optimizing the program and minimizing misinformation about covid-19 at the local, cluster level by using pamphlets, banners, posters, or direct outreach media. Provide proper education about Covid-19 and equip officers with basic communication skills.

Keywords: Covid-19, severity perception, vulnerability, benefits, and barriers

INTISARI: FAKTOR-FAKTOR YANG MEMPENGARUHI KEPATUHAN PROTOKOL KESEHATAN PADA MASA TATANAN BARU DI BANDAR LAMPUNG

Pendahuluan: Pandemi Covid-19 menunjukkan kasus yang terus meningkat khususnya di wilayah Kecamatan Sukarame. Namun di sisi lain kesadaran masyarakat dalam penerapan protokol kesehatan masih rendah.

Tujuan: Tujuan Penelitian ini adalah diketahuinya faktor faktor yang mempengaruhi kepatuhan protokol kesehatan pada masa tatanan baru di Kecamatan Sukarame Kota Bandar Lampung tahun 2021.

Metode: Jenis penelitian kuantitatif, dengan desain crossectional. Penelitian dilakukan di Kecamatan Sukarame Kota Bandar Lampung. Jumlah populasi dan sampel ditentukan berdasarkan accidental sampling sehingga diperoleh sampel pada penelitian berjumlah 97 responden. Teknik analisis data yang digunakan 
adalah univariat, bivariat (chisquare) dan multivariat (regresi logistik berganda) Hasil: Hasil penelitian menunjukkan adanya pengaruh persepsi kerentanan $(p v=0,001)$, persepsi keparahan $(p v=0,022)$, persepsi hambatan $(p v=0,034)$ dan persepsi manfaat $(p v=0,018)$ terhadap kepatuhan protokol kesehatan pada masa tatanan baru di kecamatan Sukarame Kota Bandar Lampung.

Kesimpulan: Penelitian ini menyarankan agar mengoptimalkan program dan meminimalisisr informasi tidak benar tentang covid-19 di tingkat lokal, cluster dengan menggunakan media pamflet, spanduk, poster atau penyuluhan langsung. Memberikan edukasi benar seputar Covid-19 dan membekali petugas dengan keterampilan dasar komunikasi.

Kata Kunci: Covid-19, persepsi keparahan, kerentanan, manfaat dan hambatan.

\section{PENDAHULUAN}

Coronavirus Disease 2019

(Covid-19) merupakan penyakit menular yang disebabkan Coronavirus jenis baru. Penyakit ini diawali dengan munculnya kasus pneumonia yang tidak diketahui etiologinya sejak awal kemunculannya. Virus ini berasal dari famili yang sama dengan virus penyebab SARS dan MERS. Meskipun berasal dari famili yang sama, namun SARS-CoV-2 lebih menular dibandingkan dengan SARS-CoV dan MERS-CoV(Burhan, Fathiyah, et al., 2020). Awal tahun 2020 penyebaran virus begitu massif sehingga WHO menetapkan status pandemi. Sampai saat ini telah dipastikan terdapat kurang lebih 65 negara yang terjangkit virus ini (Burhan, Fathiyah, et al., 2020).

Kasus Covid-19 di seluruh dunia telah menembus 133 juta kasus pada Senin (01/10/2020). Jumlah pasien pulih sebanyak 30.121.9376. Sedangkan korban meninggal mencapai 1.118.431 jiwa. Amerika Serikat (AS) masih menjadi negara dengan kasus Covid-19 tertinggi yaitu 8,3 juta kasus. India dengan 7,5 juta kasus (WHO, 2020). Pandemi Covid-19 melanda Indonesia sejak Maret 2020, pada Januari 2021 terdata sebanyak 927.380 kasus dan menempatkan di urutan ke 21 di dunia (Kemenkes RI, 2020c). Provinsi Lampung menempati urutan 26 dengan 8,352 kasus $(0,4 \%)$ dari kasus nasional (Dinkes Prov Lampung, 2021).
Adapun daerah dengan kasus tetinggi adalah Kota Bandar Lampung dengan 3184 kasus $(38,1 \%)$ (Dinkes Kota Bandar Lampung, 2020). Sementara itu, kasus Covid-19 tertinggi berdasarkan kecamatan sampai tanggal 17 Januari 2021 adalah Kecamatan Sukarame dengan 316 kasus (10\%) dan 20 kematian (9\%), angka ini merupakan angka kematian tertinggi di seluruh kecamatan yang ada di Kota Bandar Lampung. (Dinkes Prov Lampung, 2020).

Melihat penyebaran virus yang sedemikian cepat maka Perhimpunan Dokter Paru Indonesia (Burhan, Fathiyah, et al., 2020) menjelaskan beberapa rekomendasi langkah pencegahan yang dianjurkan oleh PDPI adalah mencuci tangan anda dengan sabun dan air atau menggunakan hand sanitizer berbasis alkohol, menghindari menyentuh mata, hidung dan mulut dengan tangan yang belum dicuci, menghindari kontak dengan orang yang sedang sakit, menggunakan masker, tetap tinggal di rumah saat sakit, menutup mulut dan hidung saat batuk atau bersin, membersihkan disinfeksi secara rutin dan lain sebagainya. Langkah langkah pencegahan Covid 19 diberlakukan setelah pada 28 Mei 2020 Pemerintah Pusat melalui Kementerian Perencanaan Pembangunan Nasional, Kementerian Luar Negeri dan Tim Gugus Tugas Penanganan Covid-19 menyampaikan Protokol Masyarakat 
Produktif dan Aman Covid-19 menuju Normal Baru (new normal) dan hidup berdampingan dengan Covid-19 sebagai upaya pencegahan penularan Covid-19 dengan menerapkan protokol kesehatan normal baru, yaitu: (1) Cuci tangan; (2) Menghindari menyentuh area wajah; (3) Menerapkan etika batuk dan bersin; (4) Gunakan masker saat keluar rumah atau berinteraksi dengan orang lain; (5) Jaga jarak sosial; (6) Isolasi mandiri.; dan (7) Menjaga kesehatan (berjemur sinar matahari pagi, mengonsumsi makanan bergizi, dan olahraga ringan) (Kemenkes RI, 2020).

Penerapan protokol kesehatan dalam rangka mengurangi kasus covid19 sangat penting dilakukan karena virus corona menyerang sistem pernapasan manusia. Covid-19 menular antarmanusia terutama dari orang terdekat melalui cipratan liur (droplet) yang dikeluarkan seseorang dari mulut atau hidung ketika bersin, batuk, bahkan saat berbicara. Droplet dapat jatuh dan menempel pada benda yang jika tersentuh tangan berpotensi menjadi jalur transmisi penularan Covid-19. Oleh itu protokol kesehatan penggunaan masker dapat melindungi diri dan orang lain dari masuknya droplet. Droplet bisa meluncur 2 meter saat bicara tanpa menggunakan masker oleh karenanya menjaga jarak san mengurangi kerumunan dapat mengurangi penularan. Virus covid merupakan material kecil yang terbungkus protein dan lemak, sabun dapat melarutkannya hingga hancur dan mati, oleh sebab itu mencuci tangan pakai sabun upaya untuk membunuh virus dan mencegah penularan.

Upaya pencegahan dengan penerapan protokol kesehatan merupakan tanggung jawab bersama. Faktanya dari pengamatan masih banyak masyarakat yang mengabaikan protokol kesehatan. Badan Pusat Statistik mempublikasikan hasil penelitian terbaru tentang perilaku masyarakat di masa pandemi Covid-19 pada subjek khusus tentang penerapan protokol kesehatan (BPS, 2020). Hasil penelitian (Kementerian Kesehatan RI, 2020a) menunjukkan bahwa persentase tertinggi tempat-tempat yang tidak menerapkan protokol kesehatan adalah di pasar tradisional atau pedagang kaki lima (17,3\%) tempat ibadah $(5,78 \%)$, tempat kerja $(2,08 \%)$ mall/plaza (1,69\%) dan pelayanan publik $(1,40 \%)$. Data tentang penerapan protokol kesehatan menurut lokasi dengan perolehan persentase yang paling rendah adalah di pasar tradisional, dimana menjaga jarak terdistribusi hanya $47,16 \%$, mencuci tangan sebanyak $51,41 \%$, dan menggunakan masker 82,62\%. Di lokasi mall/plaza/ pusat perbelanjaan pelaksanaan protokol kesehatan menjaga jarak adalah 66,97\%, mencuci tangan adalah $77,68 \%$, dan penggunaan masker adalah 9,44\%. Perilaku jaga jarak paling banyak dilakukan di tempat pelayanan publik yaitu $92,09 \%$, perilaku mencuci tangan paling banyak dilaksanakan di lokasi tempat kerja yaitu $82,56 \%$, dan penggunaan masker ada di lokasi tempat pelayanan publik yaitu $94,83 \%$. Data data tersebut menunjukkan adanya kesenjangan antara kebijakan pencegahan Covid-19 dengan perilaku pencegahan yang dilakukan masyarakat.

Kampanye pencegahan di masa pandemi Covid-19, kembali digaungkan oleh pemerintah pada masyarakat agar diterapkan untuk memutus mata rantai penyebaran virus. Penelitian ini bertujuan untuk melihat pada tingkat individu mengenai pandangan dalam melakukan perilaku protokol kesehatan sebagai pencegahan Covid19. Konsep dasar dari perilaku tersebut mengacu pada teori Health Believe Model (HBM) (Setiyaningsih et al., 2016). Menurut Irwin Rosenstock (1974) setiap individu mempunyai penilaian kepercayaan pada tingkat kerentanan dan keparahan masingmasing sehingga melakukan upaya 
pencegahan terhadap penyakit (Glanz et al., 2008). Konsep Health Belief Model dapat memberikan penilaian pada tindakan sehat untuk mencegah Covid-19 pada tingkat individu. Sehingga akan diperoleh faktor kepercayaan yang menjadi latar belakang melakukan protokol kesehatan pencegahan Covid-19 pada Masa Tatanan Baru Masyarakat Kecamatan Sukarame Kota Bandar Lampung Tahun 2020.

Penelitian ini berupaya untuk mendeskripsikan komponen dari HBM yang didalamnya terdapat keyakinan yang merupakan representasi dari suatu ide dalam suatu kondisi yang dirasakan oleh seseorang. Sejauh ini Health Belief Model adalah teori yang paling umum digunakan dalam pendidikan kesehatan dan promosi kesehatan (Glanz et al., 2008). Oleh karenanya dasar dari pemilihan teori ini bahwa HBM merupakan teori berbasis kognisi yang merupakan kombinasi pengetahuan, pendapat, dan tindakan yang dilakukan individu yang mengacu pada kesehatan mereka. Hubungan keyakinan terhadap kesehatan dan perilaku sangat erat. Adanya pandemi secara situasional memberikan ancaman (perceived threat of injury or illness) sekaligus keuntungan dan kerugian (benefit and costs). Kosep dasar ini menjadi petunjuk berperilaku untuk memulai proses perilaku.

Penelitian ini juga difokuskan di lokasi dengan kasus terbanyak dan kasus kematian tertinggi. Bandar Lampung merupakan penyumbang kasus terbanyak di Provinsi Lampung, sedangkan kasus tertinggi dan kasus kematian terbanyak ada di Kecamatan Sukarame (Dinkes Prov Lampung, 2020). Fenomena ini yang menjadi dasar penelitian dilakukan di Kecamatan Sukarame Bandar Lampung.

\section{METODE}

Jenis penelitian kuantitatif, dengan desain crossectional. Penelitian dilakukan di Kecamatan Sukarame Kota Bandar Lampung. Jumlah populasi dilakukan Kriteria inklusi

a. Berdomisili lebih dari satu tahun di wilayah Kecamatan Sukarame

b. Berusia $>15$ tahun atau $<55$ tahun

c. Tidak mengalami gangguan mobilisasi (sakit atau cacat) dan tidak mengalami gangguang jiwa

d. Bersedia menjadi responden

e. Mampu dan memiliki gadget/personal computer

Kriteria eksklusi

a. Bukan Keluarga Kader/Petugas Kesehatan

b. Sedang menjalani isolasi mandiri karena paparan covid-19

dan sampel ditentukan berdasarkan accidental sampling sehingga diperoleh sampel pada penelitian berjumlah 97 responden. Teknik analisis data yang digunakan adalah univariat, bivariat (chisquare) dan multivariat (regresi logistik berganda)

\section{HASIL}

Analisis univariat ini bertujuan untuk menggambarkan distribusi frekuensi data mengenai faktor-faktor yang berhubungan dengan kepatuhan protokol kesehatan pada masa tatatanan baru di Kecamatan Sukarame Bandar Lampung. Penyajian univariat mendeskripsikan karakteritik responden bardasarkan usia dan Pendidikan. Kriteria usia mengacu pada ketentuan usia menurut WHO (2013) yaitu kategori usia bayi (infants): 0-1 tahun, kategori usia Anak-anak (children): 2-10 tahun, kategori usia remaja (adolescents): 1119 tahun, kategori usia dewasa (adult): 20-60 tahun dan kategori Lanjut usia (elderly): di atas 60 tahun. Adapun tingkat Pendidikan di kelompokkan menjadi Pendidikan dasar, menengah dan tinggi. Berikut disajikan data hasil analisis univariat sebagai berikut: 


\section{Distribusi Variabel Penelitian}

Tabel 1.

Distribusi Frekuensi Kepatuhan Protokol Kesehatan pada Masa Tatanan Baru, Persepsi Kerentanan, Persepsi Keparahan, Persepsi Manfaat dan Persepsi Hambatan di Kecamatan Sukarame Bandar Lampung

\begin{tabular}{llcc}
\hline \multicolumn{1}{c}{ Variabel } & \multicolumn{1}{c}{ Kategori } & $\mathbf{n}$ & $\%$ \\
\hline Usia & $<19$ tahun (anak-anak) & 11 & 11,3 \\
& 20-60 tahun (dewasa) & 77 & 79,4 \\
& $>60$ tahun (lansia) & 9 & 9,3 \\
\hline Jenis Kelamin & Laki-laki & 42 & 43,3 \\
& Perempuan & 55 & 56,7 \\
\hline Pendidikan & SMP & 8 & 8,2 \\
& SMA & 37 & 38,1 \\
& PT & 52 & 53,6 \\
\hline Kepatuhan protokol & Patuh & 59 & 60.8 \\
kesehatan & Kurang patuh & 38 & 39.2 \\
\hline Persepsi Kerentanan & Positif & 61 & 62.9 \\
& Negatif & 36 & 37.1 \\
\hline Persepsi Keparahan & Positif & 51 & 52.6 \\
& Negatif & 46 & 47.4 \\
\hline Persepsi Manfaat & Positif & 55 & 56.7 \\
& Negatif & 42 & 43.3 \\
\hline Persepsi Hambatan & Positif & 54 & 55,7 \\
& Negatif & 43 & 44,3 \\
\hline
\end{tabular}

Tabel di 1 mendeskripsikan kondisi demografis responden berdasarkan usia, jenis kelamin dan tingkat pendidikan. Deskripsi usia responden dikategorisasikan berdasarkan ketentuan WHO, terdeskripsi usia paling banyak adalah usia dewasa (20-60) tahun yaitu $(79,4 \%)$. Gambaran demografis secara gender terdistribusi responden jenis kelamin perempuan lebih banyak (56,7\%) dibandingkan responden laki laki (43,3\%). Adapun Responden dengan tingkat pendidikan perguruan tinggi lebih banyak (53,6\%) dibandingkan yang lainya.
Distribusi kepatuhan tergambar bahwa bahwa dari 97 responden yang menjawab angket penelitian terdistribusi sebanyak $59(60,8 \%)$ yang mematuhi protokol kesehatan di masa tatanan baru, namun masih terdapat $38(39,2 \%)$ responden yang kurang mematuhi protokol kesehatan di masa tatanan baru. Adapun persepsi responden yang dilihat dari persepsi kerentanan, diketahui $62,9 \%$ memiliki persepsi yang positif, pada persepsi keparahan terdistribusi sebanyak $52,6 \%$ yang positif. Pada persepsi manfaat terdistribusi sebanyak $56,7 \%$ yang positif. 
Tabel 2.

Distribusi Persepsi Kerentanan dengan Kepatuhan Protokol Kesehatan di Kecamatan Sukarame Bandar Lampung

\begin{tabular}{|c|c|c|c|c|c|c|c|c|}
\hline \multirow[t]{3}{*}{$\begin{array}{l}\text { Persepsi } \\
\text { Kerentanan }\end{array}$} & \multicolumn{4}{|c|}{$\begin{array}{c}\text { Kepatuhan Protokol } \\
\text { Kesehatan }\end{array}$} & \multirow{2}{*}{\multicolumn{2}{|c|}{ Total }} & \multirow[t]{3}{*}{$\begin{array}{c}P \\
\text { value }\end{array}$} & \multirow[t]{3}{*}{$\begin{array}{c}\text { OR } \\
95 \% \mathrm{Cl}\end{array}$} \\
\hline & \multicolumn{2}{|c|}{ Patuh } & \multicolumn{2}{|c|}{$\begin{array}{l}\text { Kurang } \\
\text { Patuh }\end{array}$} & & & & \\
\hline & $\mathrm{n}$ & $\%$ & $\mathrm{n}$ & $\%$ & $\mathrm{~N}$ & $\%$ & & \\
\hline Positif & 45 & 73,8 & 16 & 26,2 & 61 & 100 & 0,001 & 4,4 \\
\hline Negatif & 14 & 38,9 & 22 & 61,1 & 36 & 100 & & $(1,8-10,6)$ \\
\hline Total & 59 & 60,8 & 38 & 39,2 & 97 & 100 & & \\
\hline
\end{tabular}

Berdasarkan tabel di atas melakukan protokol kesehatan di masa diketahui bahwa dari 61 responden tatanan baru. Hasil uji statistik yang memiliki persepsi kerentanan diperoleh nilai $p v=0,001$. Diperoleh positif terdapat sebanyak 45 nilai OR $(95 \% \mathrm{Cl})$ sebesar $4,4(1,8-10,6)$. responden $(73,8 \%)$ yang patuh

Tabel 3.

Distribusi Persepsi Keparahan dengan Kepatuhan Protokol Kesehatan di Kecamatan Sukarame Bandar Lampung

\begin{tabular}{|c|c|c|c|c|c|c|c|c|}
\hline \multirow[t]{3}{*}{$\begin{array}{l}\text { Persepsi } \\
\text { Keparahan }\end{array}$} & \multicolumn{4}{|c|}{$\begin{array}{c}\text { Kepatuhan Protokol } \\
\text { Kesehatan }\end{array}$} & \multirow{2}{*}{\multicolumn{2}{|c|}{ Total }} & \multirow[t]{3}{*}{$\begin{array}{c}P \\
\text { value }\end{array}$} & \multirow[t]{3}{*}{$\begin{array}{c}\text { OR } \\
95 \% \mathrm{Cl}\end{array}$} \\
\hline & \multicolumn{2}{|c|}{ Patuh } & \multicolumn{2}{|c|}{$\begin{array}{l}\text { Kurang } \\
\text { Patuh }\end{array}$} & & & & \\
\hline & $\mathrm{n}$ & $\%$ & $n$ & $\%$ & $\mathrm{~N}$ & $\%$ & & \\
\hline Positif & 37 & 72,5 & 14 & 27,5 & 51 & 100 & 0,022 & 2,8 \\
\hline Negatif & 22 & 47,8 & 24 & 52,2 & 46 & 100 & & $(1,2-6,7)$ \\
\hline Total & 59 & 60,8 & 38 & 39,2 & 97 & 100 & & \\
\hline
\end{tabular}

Berdasarkan tabel di atas melakukan protokol kesehatan di masa diketahui bahwa dari 51 responden tatanan baru. Hasil uji statistik yang memiliki persepsi keparahan diperoleh nilai $p v=0,022$. Diperoleh positif terdapat sebanyak 37 nilai OR $(95 \% \mathrm{Cl})$ sebesar $2,8(1,2-6,7)$. responden $(72,5 \%)$ yang patuh

Tabel 4.

Hubungan Persepsi Manfaat dengan Kepatuhan Protokol Kesehatan di Kecamatan Sukarame Bandar Lampung

\begin{tabular}{|c|c|c|c|c|c|c|c|c|}
\hline \multirow[t]{3}{*}{$\begin{array}{l}\text { Persepsi } \\
\text { Manfaat }\end{array}$} & \multicolumn{4}{|c|}{$\begin{array}{c}\text { Kepatuhan Protokol } \\
\text { Kesehatan }\end{array}$} & \multirow{2}{*}{\multicolumn{2}{|c|}{ Total }} & \multirow[t]{3}{*}{$\begin{array}{c}P \\
\text { value }\end{array}$} & \multirow[t]{3}{*}{$\begin{array}{c}\text { OR } \\
95 \% \mathrm{Cl}\end{array}$} \\
\hline & \multicolumn{2}{|c|}{ Patuh } & \multicolumn{2}{|c|}{$\begin{array}{l}\text { Kurang } \\
\text { Patuh }\end{array}$} & & & & \\
\hline & $\mathrm{n}$ & $\%$ & $\mathrm{n}$ & $\%$ & $\mathrm{~N}$ & $\%$ & & \\
\hline Positif & 39 & 70,9 & 16 & 29,1 & 55 & 100 & 0,034 & 2,6 \\
\hline Negatif & 20 & 47,6 & 22 & 52,4 & 42 & 100 & & $(1,1-6,2)$ \\
\hline Total & 59 & 60,8 & 38 & 39,2 & 97 & 100 & & \\
\hline
\end{tabular}


Berdasarkan tabel di atas diketahui bahwa dari 55 responden yang memiliki persepsi manfaat positif terdapat sebanyak 39 responden $(70,9 \%)$ yang patuh melakukan protokol kesehatan di masa tatanan baru. Hasil uji statistik diperoleh nilai $p v=0,034$. Diperoleh nilai OR $(95 \% \mathrm{Cl})$ sebesar 2,6 $(1,1-6,2)$.

Tabel 5.

Distribusi Persepsi Hambatan Ibu dengan Kepatuhan Protokol Kesehatan di Kecamatan Sukarame Bandar Lampung

\begin{tabular}{|c|c|c|c|c|c|c|c|c|}
\hline \multirow[t]{3}{*}{$\begin{array}{l}\text { Persepsi } \\
\text { Hambatan }\end{array}$} & \multicolumn{4}{|c|}{$\begin{array}{c}\text { Kepatuhan Protokol } \\
\text { Kesehatan }\end{array}$} & \multirow{2}{*}{\multicolumn{2}{|c|}{ Total }} & \multirow[t]{3}{*}{$\begin{array}{c}P \\
\text { value }\end{array}$} & \multirow[t]{3}{*}{$\begin{array}{c}\text { OR } \\
95 \% \mathrm{Cl}\end{array}$} \\
\hline & \multicolumn{2}{|c|}{ Patuh } & \multicolumn{2}{|c|}{$\begin{array}{l}\text { Kurang } \\
\text { Patuh }\end{array}$} & & & & \\
\hline & $\mathrm{n}$ & $\%$ & $\mathrm{~N}$ & $\%$ & $\mathrm{~N}$ & $\%$ & & \\
\hline Positif & 39 & 72,2 & 15 & 27,8 & 54 & 100 & 0,018 & 2,9 \\
\hline Negatif & 20 & 46,5 & 23 & 53,5 & 43 & 100 & & $(1,2-6,9)$ \\
\hline Total & 59 & 60,8 & 38 & 39,2 & 97 & 100 & & \\
\hline
\end{tabular}

Berdasarkan tabel $\mathrm{di}$ atas melakukan protokol kesehatan di masa diketahui bahwa dari 54 responden tatanan baru. Hasil uji statistik yang memiliki persepsi hambatan diperoleh nilai $p v=0,018$. Diperoleh positif terdapat sebanyak 39 nilai OR $(95 \% \mathrm{Cl})$ sebesar $2,9(1,2-6,9)$. responden $(72,2 \%)$ yang patuh

Tabel 6.

Tahap Pengujian Akhir Tanpa Interaksi

\begin{tabular}{lrrrrr}
\hline \multicolumn{1}{c}{ Variabel } & B & P & Exp (B) & \multicolumn{2}{c}{$95 \% \mathrm{Cl}$} \\
\cline { 5 - 7 } & & & & Lower & Upper \\
\hline Persepsi Kerentanan & 1,647 & 0,001 & 5,193 & 1,896 & 14,220 \\
\hline Persepsi Keparahan & 1,050 & 0,036 & 2,857 & 1,074 & 7,604 \\
\hline Persepi Manfaat & 1,088 & 0,032 & 2,969 & 1,100 & 8,017 \\
\hline Persepsi Hambatan & 1,368 & 0,007 & 3,926 & 1,452 & 10,613 \\
\hline Constant & $-2,738$ & 0,000 & 0,065 & & \\
\hline
\end{tabular}

Berdasarkan tabel di atas, maka diketahui bahwa dalam penelitian ini tidak ada interaksi yang masuk ke dalam model akhir regresi logistik ganda sehingga model akhir yang diperoleh adalah model tanpa interaksi. Selanjutnya variabel yang dapat masuk dalam model akhir adalah persepsi kerentanan, persepsi keparahan, persepsi manfaat dan persepsi hambatan. Berdasarkan keseluruhan proses analisis yang telah dilakukan tersebut dapat disimpulkan bahwa dari 4 (empat) variabel independen tersebut diketahui perspesi kerentanan merupakan variabel dominan yang berhubungan dengan dengan kepatuhan protokol kesehatan di masa tatanan baru.

Pada model akhir multivariate menunjukkan bahwa persepsi kerentanan merupakan variabel paling dominan berhubungan dengan kepatuhan protokol kesehatan di masa tatanan baru dengan perolehan $p=0,001$ dan $O R=5,193$ setelah dikontrol variabel persepsi keparahan, persepsi manfaat, persepsi hambatan. Dominasi variabel persepsi kerentanan dibandingkan variabel lainnya dikarenakan perolehan nilai $p$ paling kecil dan OR paling besar artinya 
persepsi kerentanan positif lebih berpeluang untuk patuh melakukan protokol kesehatan sebesar 5 kali

\section{PEMBAHASAN}

Hasil

analisis

univariat

menunjukkan bahwa sebagian besar responden di Kecamatan Sukarame Bandar Lampung melakukan upaya pencegahan Covid-19 dengan mematuhi protokol kesehatan $(60,8 \%)$, namun masih ada responden yang tidak mematuhi protokol kesehatan di masa tatanan baru (39,8\%) dengan mengabaikan penggunaan masker, mengabaikan ketentuan untuk menjaga jarak, mengabaikan ketentuan untuk menghindari kerumunan serta tidak membiasakan diri mencuci tangan dengan sabun.

Temuan penelitian ini sejalan dengan hasil penelitian Muhith (2021) yang menjelaskan bahwa responden yang patuh terhadap penerapan protokol kesehatan Covid-19 lebih dominan yaitu sebanyak 78 orang $(74,3 \%)$ artinya masih ditemukan masyarakat yang tidak mematuhi protokol kesehatan di masa tatanan baru. Hasil penelitian tersebut tidak jauh berbeda dengan kondisi masyarakat di tempat lain dimana kepatuhan masyarakat terhadap penerapan protokol kesehatan dilakukan oleh $61,7 \%$ responden, sementara masih ditemukan masyarakat yang tidak patuh menjalankan protokol kesehatan (Widyanto, 2020).

Secara kontekstual kepatuhan protokol kesehatan di masa tatanan baru merupakan kesadaran atau kesedian seseorang menaati suatu peraturan dan norma-norma sosial yang berlaku (Nursalam, 2015). Kepatuhan yang baik mencerminkan besarnya rasa tanggung jawab seseorang terhadap aturan yang telah ditetapkan oleh pemerintah berkaitan dengan upaya pnecegahan Covid-19. Jika seseorang mematuhi protokol dibandingkan responden yang memiliki persepsi kerentanan negatif.

kesehatan maka ia telah menjalankan tanggung jawab kesehatan dirinya dan orang lain, maka setiap orang harus berusaha agar mematuhi peraturan dalam bentuk protokol kesehatan. Banyak teori yang menjelaskan bahwa perilaku seseorang di pengaruhi oleh faktor internal individu (Notoatmodjo, 2015). Kepatuhan seseorang dipengaruhi oleh perilaku kesehatan, yang pada dasarnya perilaku kesehatan merupakan suatu respon seseorang (organisme) terhadap stimulus yang berkaitan dengan sakit dan penyakit, sistem pelayanan kesehatan serta lingkungan. Adanya pandemi Covid yang sudah berjalan selama kurang lebih 2 tahun seharusnya disadari dan dipahami masyarakat sebagai sebuah fenomena yang dapat mengancam kesehatannya. Perilaku patuh dengan protokol kesehatan dijadikan sebagai upaya pencegahan dan perilaku tidak patuh dengan protokol kesehatan akan memperburuk situasi dan dapat meningkatkan kasus penularan covid19.

Perilaku yang tergambar dari kepatuhan protokol kesehatan di masa tatanan baru memang tidak berdiri sendiri yaitu banyak faktor yang mempengaruhinya, sehingga upaya untuk mematuhi protokol kesehatan di masa tatanan baru harus dibarengi dengan kesadaran bahwa menjalankan protokol kesehatan merupakan tanggung jawab individu terhadap lingkungan dan keberlangsungan hidup dan kesehatan masyarakat dengan melakukan upaya pencegahan penularan covid-19. Banyak faktor lain yang menyebabkan responden tidak mematuhi protokol kesehatan di masa tatanan baru diantaranya pengetahuan responden tentang covid-19, kepercayaan tentang eksistensi penyakit ini dan lain sebagainya. 
Hasil penelitian masih menemukan $39,2 \%$ yang mengabaikan protokol kesehatan sementara sebagian besar berusaha untuk mematuhinya. Proporsi responden yang tidak patuh dalam menjalankan protokol kesehatan bisa disebabkan oleh banyak hal, misalnya karena penelitian ini secara demografis didominasi oleh responden usia muda sehingga pada usia tersebut mereka tidak terlalu mengkhawatirkan dirinya tertular Covid-19, padahal anggapan ini justru akan memberikan dampak buruk terhadap keluarga, komunitas dan lingkungannya terutama dapat menularkan kepada orang orang yang memiliki risiko (usia tua, komorbid dan lain sebagainya). Responden usia muda merasa tidak akan mengalami keparahan jika terpapar Covid-19, belum lagi banyak informasi covid yang simpang siur dan tidak dapat dipertanggung-jawabkan justru menjadi keyakinan yang dipilih sehingga tidak terlalu peduli dengan penerapan protokol kesehatan untuk mencegah penularan Covid-19. Penyebab ketidakpatuhan dapat terjadi karena berbagai faktor baik yang berkaitan dengan karatkteristik individu atau yang berkaitan dengan faktor eksternal. Penelitian Widyanto (2020) menjelaskan bahwa faktor penghambat bagi responden mematuhi protokol kesehatan dimasa tatanan baru ini adalah ketidak-percayaannya dengan adanya Covid-19 dan faktorfaktor yang lain.

Kepatuhan yang diukur pada penelitian ini tergambar dari pertanyaan yang diajukan diantaranya adalah sejauh mana mereka percaya dengan eksistensi Covid-19. Kepercayaan ini memberikan kontribusi terhadap keyakinan dan perilaku serta implikasinya. Seseorang yang tidak memercayai adanya covid tentunya tidak akan melakukan upaya apapun untuk mencegahnya. Pertanyaan berikutnya adalah bagian dari struktur kesetujuan atau kepercayaan seseorang terhadap
Covid-19 serta upaya penerapan protokol kesehatan. Protokolat utama dalam upaya pencegahan Covid-19 adalah menggunakan masker, menghindari kerumunan, mencuci tangan dengan sabun serta kegiatan dan aktivitas lain yang mendukung upaya protokol kesehatan yaitu mengkonsumsi makanan sehat, olah raga teratur, berjemur di bawah sinar matahari dan lain sebagainya. Seluruh pertanyaan itu adalah refleksi dan implementasi dari kepercayaan seeorang terhadap eksistensi Covid-19 dan upaya pencegahannya.

Berdasarkan penjelasan tersebut maka penulis berpendapat bahwa kepatuhan protokol kesehatan sangatlah penting sebagai upaya pencegahan penyebaran Covid-19 dan menekan angka kasus Covid-19 dengan mematuhi protokol kesehatan. Perilaku terhadap sakit dan penyakit ini dengan sendirinya sesuai dengan tingkat pencegahan penyakit, yakni; perilaku sehubungan dengan peningkatan dan pemeliharaan kesehatan (health promotion behaviour), perilaku pencegahan penyakit (health prevention behaviour) dan perilaku sehubungan dengan pencarian pengobatan (health seeking behaviour). Kepatuhan adalah istilah yang digunakan untuk menggambarkan perilaku masyarakat dalam menggunakan masker, menghindari kerumunan, menjaga jarak dan mencuci tangan dengan sabun. Namun, masih ditemukan masyarakat yang kurang mematuhi protokol kesehatan tersebut.

\section{Persepsi Kerentanan}

Hasil penelitian pada variabel persepsi kerentanan ini menunjukkan bahwa persepsi responden yang dilihat dari persepsi kerentanan, diketahui $62,9 \%$ memiliki persepsi yang positif. Distribusi data tersebut menunjukkan masih terdapat sebanyak $37,1 \%$ responden yang memiliki persepsi kerentanan negatif. Persepsi 
kerentanan menunjukkan sejauh mana individu mempersepsi bahwa ia rentan untuk mengalami sakit atau terjangkit suatu penyakit, apakah ia berisiko untuk menjadi sakit atau mudah tertular dari orang lain

Hasil penelitian ini sejalan dengan gambaran dari penelitian Ummah (2020) yang menggambarkan proporsi responden yang persepsi kerentanan terhadap protokol kesehatan lebih banyak yang positif yaitu sebanyak $58,3 \%$. Demikian juga penelitian Rosidin, Rahayuwati dan Herawati (2020) menggambarkan tentang perilaku dan peran tokoh masyarakat dalam upaya pencegahan dan penanggulangan pandemi Covid19 , terdistribusi sebanyak $73,2 \%$ yang memiliki persepsi positif terhadap situasi pandemi yang dialaminya dan menuntutnya untuk melakukan upaya pencegahan.

Secara teori dijelaskan bahwa persepsi kerentanan merupakan salah satu komponen model kepercayaan kesehatan (health believe model) dimana komponen ini dapat digunakan untuk menjelaskan perilaku kesehatan. Persepsi kerentanan yang dirasakan atau sebagai presepsi subyektif seseorang tentang risiko terkena penyakit. Persepsi ini juga mengacu pada keyakinan tentang kemungkinan mendapatkan suatu penyakit. Artinya orang dengan perspesi kerentanan positif berarti dia meyakini dan percaya bahwa dengan mematuhi protokol kesehatan berarti meminimalisasi potensi penularan Covid-19 yang dapat mengancam kesehatannya. Persepsi ini terbentuk dari pengamatan sehari-hari diperoleh kejelasan yang akan membuat informasi tersebut akan langgeng tersimpan dalam benak sehingga membentuk persepsi.

Persepsi kerentanan responden selain diketahui dari hasil penelitian juga dapat dilihat dari pengamatan dimana responden yang memiliki persepsi kerentanan positif menyadari dan memiliki persepsi bahwa mereka rentan terhadap penyakit Covid 19 dalam tingkat yang wajar, di mana hal ini tampak dari tindakannya mematuhi kebijakan protokol kesehatan sebagaimana yang telah ditetapkan oleh pemerintah. Sebagian warga lainnya memiliki persepsi kerentanan negatif terhadap covid-19 di mana mereka mengabaikan penggunaan masker, menjaga jarak, menghindari kerumunan dan mencuci tangan dengan sabun. Responden bebas pergi kemana mana tanpa menggunakan masker dan tidak merasa biasa dengan kerumunan dan keramaian. Pada kelompok lainnya yang merasa sangat rentan terhadap penyakit ini, menunjukkan perilaku memberikan stigma kepada tenaga kesehatan, penderita, bahkan sampai menolak untuk melakukan protokol kesehatan (Simbolon, 2020). Dampak dari stigma negatif yang diberikan kepada para tenaga medis dan pasien menimbulkan efek samping, yaitu penderita enggan untuk mengatakan dengan jujur tentang kondisi tubuhnya yang akhirnya berakibat semakin banyaknya warga yang terpapar Covid-19 (Rosa \& Varwati, 2020). Kelompok masyarakat lainnya tampak kurang menaruh perhatian, sehingga tidak mempedulikan prtotokol kesehatan.

Berdasarkan penjelasan tersebut maka penulis berpendapat bahwa persepsi kerentanan memberikan kontribusi terhadap perilaku kesehatan. Responden yang memiliki persepsi kerentanan tentang pandemi Covid-19 akan memberikan kesadaran bahwa dirinya merupakan objek yang rentan untuk tertular atau menularkan jika tidak melakukan upaya pencegahan dengan mematuhi langkah protokol kesehatan. Untuk melahirkan persepsi kerentanan positif kepada masyarakat adalah dengan memperbanyak informasi infoasi yang benar tentang penularan Covid-19 khususnya di kalangan muda. 


\section{Persepsi Keparahan}

Hasil penelitian pada variabel persepsi keparahan terdistribusi sebanyak $52,6 \%$ yang positif. Data tersebut menunjukkan bahwa lebih dari separuh responden memiliki persepsi keparahan positif tentang covid-19 dan mendorongnya melakukan upaya pencegahan dari bahaya terpapar covid-19 dengan melakukan proporsi kesehatan

Proporsi persepsi positif yang lebih dominan sejalan dengan hasil penelitian Ummah (2020), Widyanto (2020) dan Muhith (2021) dimana lebih banyak responden memiliki sikap keparahan positif dibandingkan yang negatif. Kondisi ini memberikan keuntungan tersendiri karena persepsi keparahan menjadi proses psikologis yang memegang peranan penting terbentuknya perilaku kesehatan.

Konsep tentang persepsi keparahan ini dijelaskan oleh Maulana (2010) mengidentifikasikan sebagai keparahan/keseriusan yang dirasakan. keseriusan yang dirasakan bermaksud sebagai presepsi seseorang terhadap tingkat keparahan penyakit yang diderita individu (Glanz et al., 2008). Sehingga perceived seriousness juga memiliki hubungan dengan perilaku sehat, jika presepsi keparahan individu tinggi maka ia akan berperilaku sehat. Perceived seriousness ini juga mengacu pada tingkat keparahan kondisi (konsekuensi medis yang meliputi kecacatan, rasa sakit, atau kematian) dan dampaknya terhadap gaya hidup (konsekuensi social yang meliputi kemampuan kerja, hubungan social, dan lain-lain). Contohnya individu percaya bahwa dengan tidak mematuhi protokol kesehatan dapat menyebabkan tertular Covid-19

Persepsi tingkat keparahan Covid-19 pada responden dari perspektif penelitian ini tergolong positif. Fakta ini menunjukkan bahwa jumlah kasus harian karena covid 19 terus meningkat diiringi juga dengan peningkatan kasus kematian karena
Covid-19. Persepsi tingkat keparahan dari perspektif warga yang cenderung negatif tampak dari tidak adanya pola perilaku yang dominan yang ditunjukkan oleh masyarakat dalam kepatuhan menjalankan protokol kesehatan di masa tatanan baru. Sebagian warga relatif menyadari bahwa tingkat keparahan penyakit ini tergolong tinggi, di mana mereka ikut sosialisasi tentang Covid-19 dan ikut peduli menghadapi Covid-19 (Agustina, 2020). Sebagian responden lainnya terlihat bersikap tidak peduli, apatis, atau tidak mau tahu mengenai tingkat keparahan Covid-19. Hal ini nampak dari banyaknya warga yang belum paham soal penerapan protokol kesehatan, masih ditemukan responden tidak menggunakan masker, mengabaikan kerumunan, tidak menjaga jarak dan tidak membiasakan mencuci tangan dengan sabun karena mereka menganggap kematian karena penyakit Covid adalah sudah ketentuan dari Yang Maha Kuasa.

Berdasarkan penjelasan tersebut maka penulis berpendapat bahwa persepsi keparahan merupakan proses menerima informasi yang didapat kemudian meresnpon keadaan atau kondisi di sekitarnya yang berkaitan dengan kondisi yang dapat mengancam kesehatannya, persepsi ini akan menumbuhkan beban tanggung jawab sehingga dapat membentuk peran dan aksi misalnya dalam bentuk tanggung jawabnya untuk mematuhi protokol kesehatan sebagai langkah pencegahan penularan covid-19.

\section{Persepsi Manfaat}

Hasil penelitian pada variabel persepsi manfaat ini menunjukkan bahwa dari terdistribusi sebanyak $56,7 \%$ responden yang memiliki persepsi manfaat yang positif. Adapun responden yang mempunyai persepsi manfaat dalam kategori negatif sebanyak 43,3\%. Persepsi manfaat adalah anggapan individu mempersepsi manfaat dari metode atau cara-cara 
pencegahan

yang

disarankan/direkomendasikan untuk mereduksi risiko atau keseriusan penyakit yang akan diderita akibat perilaku kesehatan yang kurang baik.

Hasil penelitian ini sejalan dengan hasil penelitian Priyadarsini dan Suresh (2020) dan Yanti, dkk (2020) yang menggambarkan kondisi persepsi responden dimana persepsi responden lebih banyak yang positif dibandingkan dengan persepsi negatif. Fenomena ini menunjukkan bahwa anggapan atau persepsi umumnya responden sudah mendukung berjalannya masa tatanan baru dengan penerapan protokol kesehatan, namun demikian tetap masih ada respoden yang memiliki persepsi negatif

Beberapa hasil penelitian di atas sejalan dengan teori persepsi manfaat sebagai salah satu komponen HBM. Persepsi ini disebut juga sebagai manfaat yang dirasakan. Ini mengacu pada persepsi seseorang tentang efektivitas berbagai tindakan yang tersedia untuk mengurangi ancaman penyakit atau penyakit (atau untuk menyembuhkan penyakit) (Wibowo, 2016). Jalannya tindakan yang dilakukan seseorang untuk mencegah (atau menyembuhkan) penyakit atau penyakit bergantung pada pertimbangan dan evaluasi dari yang dirasakan dan manfaat yang dirasakan, sehingga orang tersebut akan menerima tindakan kesehatan yang disarankan jika dianggap bermanfaat. Ketika seseorang yakin bahwa ia rentan terhadap sesuatu penyakit dan juga sudah mengetahui bahaya penyakit tersebut, ia tidak akan begitu saja menerima tindakan kesehatan yang dianjurkan kepadanya, kecuali bila ia yakin bahwa tindakan tersebut dapat mengurangi ancaman penyakit dan ia sanggup melakukannya.

Pemerintah hakikatnya memiliki perspsi tentang manfaat protokol kesehatan yang sangat kuat, di mana peraturan-peraturan dibentuk hingga kampanye lewat media sosial sangat gencar. Pemerintah yakin bahwa protokol kesehatan bermanfaat untuk mencegah penyebaran Covid-19 semakin meluas. Persepsi manfaat menurut warga juga tampak bervariasi sepert pada persepsi-persepsi lainnya. Sebagian dari warga merasa dapat mengakses manfaat yang diperoleh dari protokol kesehatan di masa tatanan baru dan program pemerintah provinsi yang bertujuan memutus rantai penyebaran Covid-19. Mereka tampak lebih sadar pentingnya PHBS, memiliki banyak waktu berkualitas dengan anggota keluarga, dapat mengerjakan hobi, menekan biaya transportasi, paham dengan teknologi, dan menekan polusi (Prayugi, 2020). Sebagian warga lainnya cenderung skeptis, merasa ragu bahwa protokol kesehatan bermanfaat untuk pencegahan penularan Covid-19 dan masih ada kelompok responden yang juga merasa ragu terhadap manfaat dan ketepatan sasaran dari pelaksanaan protokol kesehatan.

Berdasarkan penjelasan tersebut paka penulis berpendapat bahwa persepsi manfaat responden adalah pengamatan sebagai hasil kombinasi penglihatan, penciuman, pendengaran serta pengalamannya pada seluruh aspek proses dan kegiatan sehari- hari yang berfokus pada siatuasi kesehatan.

\section{Persepsi Hambatan}

Hasil penelitian pada variabel kebutuhan individu ini menunjukkan distribusi responden sebanyak (55,7\%) memiliki persepsi hambatan yang positif. Persepsi tentang hambatan dari perspektif penelitian ini terutama adalah kepatuhan responden dalam menerapkan protokol kesehatan di masa tatanan baru. Salah satu persoalan makin meningkatnya jumlah pasien positif Covid-19 adalah karena responden tidak mematuhi protokol kesehatan dengan tidak menggunakan masker, mengabaikan jaga jarak dan kerumunan dan tidak membiasakan diri 
mencuci tangan dengan sabun. Probabilitas tertular semakin tinggi jika responden tidak mematuhi protokol kesehatan.

Penelitian Nirmala (2018) dan Puspitasari (2017) mendukung penelitian dimana secara umum hasil penelitian menunjukkan bahwa responden secara umum merasakan rintangan atau hambatan dalam melaksanakan protokol kesehatan di masa tatanan baru karena berbeda dengan kebiasaan lama. Persepsi responden tentang hambatan mematuhi protokol kesehatan sangat bervariasi. Diantaranya adalah adanya stigma untuk para pasien Covid-19. Mereka yang dinyatakan positif harus dijauhi, karena mereka akan membawa petaka. Mereka harus disingkirkan karena mereka membawa bencana. Oleh karena adanya stigma ini, pada saat dilakukan pemeriksaan massal, sejumlah warga tidak mau memberikan informasi secara jujur kepada petugas kesehatan terkait riwayat bepergian/perjalanannya. Bahkan mereka cenderung marah ketika ditanya mengenai orang-orang yang berkontak dengan mereka dan riwayat interaksi/aktivitas mereka bersama orang-orang yang berkontak tersebut. Stigma negatif ini tidak hanya ditujukan kepada para pasien yang positif, namun juga kepada kelompok warga yang rentan terhadap penyakit ini, yakni kelompok usia lanjut dan kelompok yang mempunyai penyakit penyerta.

Selain itu secara psikologis mereka juga mengalami personal fable, yaitu suatu keyakinan bahwa mereka adalah individu yang spesial dan unik sehingga tidak ada kesulitan atau masalah yang bisa mempengaruhi mereka terlepas dari apapun yang mereka lakukan. Hal ini membuat mereka mempersepsi bahwa mereka tidak akan mungkin tertular. Persepsi hambatan lainnya adalah persepsi masyarakat tentang ketidakmampuan pemerintah dalam memberikan layanan yang menjangkau warga sepenuhnya, seperti terbatasnya kapasitas rumah sakit rujukan dan jumlah rumah sakit yang ditunjuk (Lumbanrau \& Hajid, 2020). Begitu pula halnya dengan fasilitas yang disediakan di rumah sakit ataupun di tempat-tempat lainnya yang ditunjuk untuk menjadi tempat perawatan pasien (wisma, hotel, dsb). Fasilitas alat-alat pelindung baik untuk para tenaga medis kurang memadai sehingga risiko para tenaga medis untuk tertular sangat tinggi.

\section{Berdasarakan}

penjelasan tersebut maka penulis berpendapat bahwa adanya hambatan dan rintangan yang tersimpan dalam persepsi individu di masa tatanan baru ini merupakan tantangan yang harus dijalani sebagai upaya atau tanggung jawabnya terhadap kesehatan diri dan orang orang di lingkungannya. Kesadaran ini memberikan keuntungan agar kasus covid-19 bisa ditekan dan dikendalikan disadari bukan hanya tanggung jawab pemerintah atau petugas kesehatan saja tetapi juga tanggung jawab individu baik tanggung jawab secara fisik atau tanggung jawab secara moral. Kepatuhan menerapkan protokol kesehatan merupakan upaya untuk mencegah dan mendeteksi sedini mungkin gangguan dan hambatan serta penularan covid-19 yang semakin meluas dan mengancam kesehatan individu dan komunitas.

\section{Hubungan Persepsi Kerentanan dengan Kepatuhan Protokol Kesehatan}

Hasil uji statistik dimana diperoleh $p=0,001$.

Hasil penelitian ini sejalan dengan teori Wibowo (2014) yang menjelaskan persepsi kerentanan adalah salah satu persepsi yang kuat untuk seseorang mengadopsi perilaku kesehatan. Penelitian ini menunjukkan bahwa responden yang merasa dirinya rentan terkena penyakit covid-19 maka akan mematuhi prtokol kesehatan 
sebagaimana yang dianjurkan di masa tatanan baru yaitu perilaku kebiasaan lama diganti dengan kebiasaan baru sebagai upaya mencegah terjadinya covid-19 dan sebaliknya.

Hasil penelitian ini sejalan dengan penelitian Puri (2016) yang mengungkapkan bahwa ada pengaruh antara persepsi kerentanan dan kelengkapan status imunisasi yang diberikan ibu kepada anak. Ibu yang merasa anaknya rentan terkena penyakit yang dapat dicegah dengan imunisasi akan melakukan tindakan pencegahan dengan vaksin dan sebaliknya. penelitian Wakhida (2016) yang mengungkapkan bahwa ada persepsi kerentanan dan penggunaan VCT. Ibu hamil yang memiliki persepsi kerentanan yang tinggi tentang penyakit HIV/AIDS akan meningkatkan penggunaan VCT. Penelitian Indrian (2014) yang mengungkapkan bahwa ada hubungan persepsi tentang kerentanan penyakit dengan pelayanan kesehatan pada health belief model. Hal ini menunjukkan bahwa kerentanan penyakit meningkat maka pelayanan kesehatan pada health belief model akan meningkat.

Kerentanan akan penyakit covid19 yang dirasakan responden pada umumnya belum banyak memotivasi untuk mematuhi protokol kesehatan. Kebanyakan orang baru bertindak setelah mengalami penyakit tersebut sehingga masih didapatkan responden yang tidak mematuhi protokol kesehatan di masa tatanan baru. Ketidakpatuhan protokol kesehatan berkaitan erat dengan peningkatan jumlah kasus positif Covid-19. Tidak semua pelanggaran yang dilakukan adalah bentuk ketidakpatuhan. Masih ada warga yang tidak sengaja melakukan pelanggaran karena belum sepenuhnya memahami bahaya penularan Covid-19 dan manfaat penerapan protokol kesehatan. Ketidakpatuhan yang disebabkan Persepsi kerentanan (perceived susceptibility), usia di bawah 50 tahun memiliki kondisi tubuh yang masih kuat dan imunitas yang baik sehingga tidak mudah terpapar virus.

$\begin{array}{rrr}\text { Persepsi } & \begin{array}{c}\text { kerentanan } \\ \text { inilah yang membuat banyak }\end{array}\end{array}$
masyarakat tidak mematuhi protokol kesehatan, terlebih bagi mereka yang tinggal sendiri tanpa ada orang berusia lanjut di rumahnya, sehingga merasa tidak beresiko menularkan virus. Upaya pemerintah menghadirkan public figure dalam pemberian informasi melalui media massa, baik melalui siaran khusus, iklan layanan masyarakat merupakan upaya positif yang diharapkan mampu menggugah kesadaran masyarakat untuk mematuhi protokol kesehatan di masa tatanan baru.

\section{Hubungan Persepsi Keparahan dengan Kepatuhan Protokol Kesehatan \\ Diketahui bahwa hasil uji} statistik diperoleh nilai $p v=0,022$, berarti ada hubungan persepsi keparahan dengan kepatuhan protokol kesehatan di masa tatanan baru di Kecamatan Sukarame Bandar Lampung Hasil penelitian ini sejalan dengan penelitian Madawamah (2021) yang menyimpulkan bahwa persepsi keparahan memiliki hubungan signifikan dengan kepatuhan protokol kesehatan $(p=0,001 ; O R=3,7)$, demikian juga dengan hasil penelitian Aswadi (2020) yang menunjukkan kesamaan hasil penelitian bahwa ada hubungan yang erat antara persepsi keparahan dengan kepatuhan protokol kesehatan $(p=0,001 ; O R=4,01)$.

Masih adanya proporsi responden yang memiliki persepsi keparahan negatif dibandingkan yang bersikap positif terhadap kepatuhan protokol kesehatan di masa tatanan membuktikan bahwa meskipun upaya sosialisasi telah dilakukan tetapi masih ada yang memiliki persepsi keparahan negatif karena responden tidak merasakan imbas atau tidak terpapar penyakit ini secara langsung. 
Sedangkan responden yang memiliki persepsi keparahan positif tetapi tidak patuh protokol kesehatan karena pertimbangan pribadi atau kepercayaannya.

Hasil penelitian ini sejalan dengan penelitian Ummah (2021) yang mengungkapkan bahwa ada pengaruh antara persepsi keparahan dengan perilaku pencegahan $3 \mathrm{M}$, penelitian ini lebih lanjut menjelaskan bahwa makin parah suatu penyakit maka seseorang akan melakukan upaya untuk melakukan pencegahan yaitu mematuhi protokol kesehatan. Ada pula penelitian Sutrisni (2016) yang mengungkapkan bahwa ada pengaruh persepsi keparahan/persepsi keseriusan dan tes HIV bahwa responden yang memiliki persepsi bahwa penyakit serius yang diketahui lebih dini reponden akan melakukan pencegahan salah satunya tes HIV untuk mengetahui status terjangkit atau tidaknya dengan penyakit AIDS.

Hasil penelitian ini relevan dengan teori Health Belief Model. Keparahan yang dirasakan menentukan ada tidaknya pencegahan terhadap penyakit. Persepsi keseriusan sering didasarkan pada informasi medis, pengetahuan atau keyakinan seseorang bahwa dia akan mendapat kesulitan akibat penyakit yang akan mempersulit hidupnya Glanz (2009). Keparahan yang dirasakan menentukan ada tidaknya tindakan pencegahan yang dilakukan terhadap penyakit tersebut dalam hal ini penyakit covid-19, yang membuat individu bersedia untuk mencari informasi kemudian melaksanakan nya dan mematuhi protokol kesehatan untuk mencegah covid-19. Hal ini dikarenakan mereka tidak ingin terkena penyakit tersebut sehingga akan melakukan usaha pencegahan.

Berdasarkan hasil penelitian tersebut maka penulis berpendapat bahwa persepsi keparahan dapat memberikan efek secara psikologis terhadap perubahan perilaku dalam hal ini adalah kepatuhan menjalankan protokol kesehatan. Ketidakpatuhan protokol kesehatan berkaitan erat dengan peningkatan jumlah kasus positif Covid-19. Tidak semua pelanggaran yang dilakukan adalah bentuk ketidakpatuhan. Masih ada warga yang tidak sengaja melakukan pelanggaran karena belum sepenuhnya memahami bahaya penularan Covid-19 dan manfaat penerapan protokol kesehatan. Ketidakpatuhan yang disebabkan persepsi keparahan (perceived severity), menganggap bahwa jika terpapar virus tidak akan parah dan tingkat kesembuhan akan lebih cepat dan tidak ada figure atau tokoh yang dapat dijadikan sebagai panutan atau contoh, tidak ada sanksi yang tegas dan memberatkan, serta tidak ada tayangan di media massa yang mampu mendorong kesadaran untuk mematuhi aturan protokol kesehatan dimasa tatanan baru. Oleh karenanya intervensi kesehatan yang dapat dilakukan adalah bahwa masyarakat mendapatkan akses informasi yang tepat tentang Covid-19 secara gamblang dan jelas sehingga masyarakat dapat memahami dengan seksama kondisi pandemi yang luas ini disebabkan oleh karena perilaku masyarakat yang tidak mematuhi protokol kesehatan.

\section{Hubungan Persepsi Manfaat dengan Kepatuhan Protokol Kesehatan}

Hasil uji statistik diperoleh nilai $p v=0,034$, berarti ada hubungan persepsi manfaat dengan kepatuhan protokol kesehatan di masa tatanan baru di Kecamatan Sukarame Bandar Lampung.

Hasil penelitian ini sejalan dengan penelitian Wakhida (2016) yang mengungkapkan bahwa ada pengaruh antara persepsi manfaat dan penggunaan VCT. Responden yang memiliki persepsi manfaat yang tinggi tentang penyakit HIV/AIDS akan menggunakan tes VCT. Penelitian 
Ningrum (2016) mengungkapkan bahwa ada pengaruh antara persepsi manfaat dan kinerja kader pada pengendalian kasus tuberkulosis. Kader yang memiliki persepsi manfaat besar akan melakukan tugas dalam pengendalian kasus tuberkulosis dengan baik daripada kader yang memiliki persepsi manfaat kecil. Wigati (2016) mengungkapkan bahwa ada pengaruh persepsi manfaat dan pelaksanaan tes IVA. Responden yang semakin merasakan persepsi manfaat dari suatu tindakan untuk menghindari penyakit tersebut, maka akan lebih memilih melakukan tindakan tersebut.

Berdasarkan teori Health Belief Model, Rosenstock (1982) menyatakan bahwa individu percaya pada suatu perilaku bermanfaat bagi dirinya dan lingkungan maka individu tersebut akan melakukan perilaku tersebut namun apabila manfaat yang didapat tidak sesuai maka perilaku tersebut tidak akan terjadi. Persepsi manfaat bagi responden jika mematuhi protokol kesehatan agar responden tersebut dapat terhindar dan menjadi salah satu upaya pencegahan covid-19 membuat responden merasa aman dengan mematuhi protokol kesehatan. Manfaat yang dirasakan (perceived benefit) merupakan pendapat seseorang tentang kegunaan suatu perilaku baru dalam menurunkan risiko penyakit.

Ketidakpatuhan penerapan protokol kesehatan berkaitan erat dengan peningkatan jumlah kasus positif Covid-19. Tidak semua pelanggaran yang dilakukan adalah bentuk ketidakpatuhan. Masih ada warga yang tidak sengaja melakukan pelanggaran karena belum sepenuhnya memahami bahaya penularan Covid-19 dan manfaat penerapan protokol kesehatan. Ketidakpatuhan warga disebabkan beberapa faktor, antara lain adanya persepsi manfaat (percieved benefit), kebiasaan berkumpul dan merasa penerapan protokol kesehatan tidak bermanfaat (sia-sia) seiring keluarnya istilah new normal dan adanya pelonggaran PPKM. Penelitian ini menunjukkan bahwa responden akan mematuhi protokol kesehatan di masa tatanan baru apabila mendatangkan manfaat untuk mencegah covid-19 dan sebaliknya, sehingga presentasi responden yang tidak mematuhi protokol kesehatan di masa tatanan baru masih ditemukan karena kurangnya informasi mengenai vaksin tersebut.

\section{Hubungan Persepsi Hambatan dengan Kepatuhan Protokol Kesehatan}

Hasil uji statistik diperoleh nilai $p v=0,018$, berarti ada hubungan persepsi manfaat dengan kepatuhan protokol kesehatan di masa tatanan baru di Kecamatan Sukarame Bandar Lampung.

Persepsi hambatan (perceived barriers) menjadi salah satu penyebab karena diantara responden yang mengalami hambatan dalam memperoleh dan memahami informasi lengkap tentang Covid-19, baik hambatan yang berasal dari dalam diri sendiri maupun dari luar diri (lingkungan). Responden yang memiliki karakteristik yang beragam memiliki kemampuan akses informasi yang beragam pula sehingga informasi tentang Covid-19 diterima secara berbeda. Hal inilah yang memunculkan proporsi responden yang memiliki persepsi positif namun tidak mematuhi protokol kesehatan atau proporsi responden yang memiliki persepsi hambatan negatif tetapi tetap mematuhi protokol kesehatan di masa tatanan baru.

Berdasarkan penjelasan tersebut maka dalam strategi promosi yang perlu dikembangkan adalah dengan memperhatikan kelompok sasaran serta membatasi informasi informasi yang tidak benar terkait dengan Covid19. Keaktifan petugas kesehatan dalam menjalankan tugas tersebut tidak hanya berperan sebagai promotor 
tetapi juga sebagai influencer untuk mempromosikan, mensosialisasikan dan mendistribusikan informasi yang benar tentang Covid-19 sehingga dapat meyakinkan masyarakat tentang bahaya Covid-19.

Ketidakpatuhan warga terhadap penerapan protokol kesehatan berkaitan erat dengan peningkatan jumlah kasus positif COVID-19. Tidak semua pelanggaran yang dilakukan adalah bentuk ketidakpatuhan. Masih ada warga yang tidak sengaja melakukan pelanggaran karena belum sepenuhnya memahami bahaya penularan COVID-19 dan manfaat penerapan protokol kesehatan. Ketidakpatuhan warga disebabkan beberapa faktor, antara lain adanya persepsi hambatan (percieved barriers), yaitu kesulitan memahami

\section{KESIMPULAN}

Dapat ditarik kesimpulan yaitu ada hubungan persepsi kerentanan dengan kepatuhan protokol kesehatan di masa tatanan baru di Kecamatan Sukarame Bandar Lampung $(p v=0,001)$ Ada hubungan persepsi keparahan dengan kepatuhan protokol kesehatan di masa tatanan baru di Kecamatan Sukarame Bandar Lampung ( $p v=0,022)$. Ada hubungan persepsi manfaat dengan kepatuhan protokol kesehatan di masa tatanan baru di Kecamatan Sukarame Bandar Lampung ( $p v=0,034)$. Ada hubungan persepsi manfaat dengan kepatuhan protokol kesehatan di masa tatanan baru di Kecamatan Sukarame Bandar Lampung ( $p v=0,018)$. Persepsi kerentanan merupakan variabel paling dominan berhubungan dengan kepatuhan protokol kesehatan di masa tatanan baru dengan perolehan $p=0,001$ dan $O R=5,193$ setelah dikontrol variabel persepsi keparahan, persepsi manfaat, persepsi hambatan.

\section{Saran}

informasi yang diberikan pemerintah, kesulitan mengakses informasi karena peralatan komunikasi yang tidak memadai, lebih mengutamakan kegiatan ekonomi, serta ketidakpercayaan terhadap kebijakan dan pernyataan pemerintah yang tidak konsisten. Kebiasaan lama responden turut menjadi pemicu sulitnya mematuhi protokol kesehatan di masa tatanan baru. Kebanyakan responden terbiasa jarang cuci tangan kecuali untuk keperluan makan atau keperluan lain, kebiasaan tidak menggunakan masker, kebiasaan berkerumun dan salaman, kebiasaan-kebiasaan lain harus berubah dengan kebiasaan baru. Kondisi ini yang membuat responden harus beradaptasi untuk mematuhi protokol kesehatan di masa tatanan baru.

Berdasarkan hasil penelitian gambaran persepsi responden yang menggambarkan bahwa aspek

\section{DAFTAR PUSTAKA}

Burhan, E., Dwi, S. A., A, N. S., Ginanjar, E., Pitoyo, C. W., Susilo, A., Firdaus, I., Santoso, A., Juzar, D. A., Arif, S. K., Wulung, N. G. . L., Adityaningsih, D., Syam, A. F., Rasmin, M., Rengganis, I., Sukrisman, L., Damayanti, T., Wiyono, W. H., Prasenohadi, ... Aniwidyaningsih, W. (2020). Pedoman Tata Laksana Covid-19. Perhimpunan Dokter Paru Indonesia (PDPI).

Burhan, E., Fathiyah, I., \& Susanto, D. S. (2020). Peneumonia Covid 19 Diagnosis dan Penatalaksanaan di Indonesia. In Perhimpunan Dokter Paru Indonesia (Vol. 55, Issue 5). Perhimpunan Dokter Paru Indonesia (PDPI).

Burhan, E., Susanto, A. D., Sally A Nasution, E. G., Pitoyo, C. W., Susilo, A., Firdaus, I., \& IDAI, T. C.-19. (2020). Protokol Tatalaksana Covid-19. In 1. Perhimpunan Dokter Paru Indonesia (PDPI). 
Dinkes Prov Lampung. (2020). Data Pemantauan Covid-19 Kota Bandar Lampung. https: / /covid19. bandarlampungk ota.go.id/peta.html

Doremalen, N. van, Bushmaker, T., Morris, D. H., Holbrook, M. G., \& Gamble, A. (2020). Aerosol and Surface Stability of SARS-CoV-2 as Compared with SARS-CoV-1. The New England Journal of Medicine, 0-3.

Du, Z., Xu, X., Wu, Y., Wang, L., Cowling, B. J., \& Meyers, L. A. (2020). Serial Interval of an outbreak of 2019 novel coronavirus diseases (Covid-19)China, 2020. China CDC Weekly 2020. Research Letters, 26(6), 2019-2021.

Galvin, C. J., Li, Y. C. (Jack), Malwade, S., \& Syed-Abdul, S. (2020). Covid-19 preventive measures showing an unintended decline in infectious diseases in Taiwan. International Journal of Infectious Diseases, 98, 18-20. https://doi.org/10.1016/j.ijid.20 20.06.062

Glanz, K., Rimer, B. k., \& Viswanath, K. (2008). Health Behavior and Health Education; Theory, Research and Practice (4th Editio). Jossey Bass A Wiley Imprint.

Ira Nurmala, Rahman, F., Anhar, Nugroho, A., A, N., Layli, N., \& Vina Yulia. (2018). Promosi Kesehatan. Airlangga University Press.

KMK No. HK.01.07/MENKES/382/2020 tentang Protokol Kesehatan bagi Masyarakat di Tempat dan Fasilitas Umum dalam rangka Pencegahan dan Pengendalian Covid-19, Keputusan Menteri Kesehatan Republik Indonesia 2 (2020).

http://jurnalrespirologi.org/inde x.php/jri/article/view/101

Kemenkes RI. (2020a). Pedoman Pencegahan dan Pengendalian
Corona Virus deases (Covid-19). Kementrian Kesehatan, 5, 178. https: //covid19.go.id/ storage/app/media/Protokol/RE V-05_Pedoman_P2_Covid19_13_Juli_2020.pdf

Kemenkes RI. (2020b). Pedoman Perubahan Perilaku. Pedoman Perubahan Perilaku Penanganan Covid-19, 1-60.

Kemenkes RI. (2020c). Peta Sebaran Covid-19. Gugus Tugas Percepatan Penanganan Covid-19. https://covid19.go.id/petasebaran

Kementerian Kesehatan RI. (2020a). Covid-19 dalam Angka.

Kementerian Kesehatan RI. (2020b). Strategi Komunikasi Perubahan Perilaku (KPP) Dalam Pencegahan Covid-19. 1-48.

Lameshow, Wulung, N. G. . L., Hosmer, D. W., Klar, J., \& Lwanga, S. K. (1991). Adequacy of Sample Size in Health Studies. Biometrics, $\quad 47(1), \quad 347$. https: / / doi.org/10.2307/2532527

Maulana. (2010). Promosi Kesehatan (IV). Penerbit Buku Kedokteran EGC Jakarta.

Muhyiddin. (2020). Covid. The Indonesian Journal of Development Planning, IV(2), 240-252. https: //doi.org/10.1016/j.cpha.2 021.01 .002

Munardo, D. (2020). Pedoman Tata Laksana Covid 19. In Gugus Tugas Percepatan Penanganan Covid-19 (Vol. 53, Issue 9). https://doi.org/10.1017/ CBO9781107415324.004

Notoatmodjo, S. (2012). Promosi Kesehatan dan Perilaku Kesehatan (VIII (ed.)). Rineka Cipta.

Nurgraheni, D. . (2020). Zona Hijau, 102 Daerah Ini Boleh Berkegiatan Aman di Tengah Pandemi Covid19.

https: //nasional.kompas.com/re $\mathrm{ad} / 2020 / 05 / 31$ /06070081/zona- 
hijau-102-daerah-ini-boleh-

berkegiatan-aman-di-tengah-

pandemi-covid -19 ?page $=$ all

Ouassou, H., Kharchoufa, L., Bouhrim, M., Daoudi, N. E., Imtara, H., Bencheikh, N., Elbouzidi, A., \& Bnouham, M. (2020). The Pathogenesis of Coronavirus Disease 2019 (Covid-19): Evaluation and Prevention. Journal of Immunology Research, 2020(July).

https://doi.org/10.1155/2020/13 57983

Peraturan Pemerintah Nomor 21 Tahun 2020, 2019

Prasetyo, Y. T., Castillo, A. M., Salonga, L. J., Sia, J. A., \& Seneta, J. A. (2020). Factors affecting perceived effectiveness of Covid-19 prevention measures among Filipinos during Enhanced Community Quarantine in Luzon, Philippines: Integrating Protection Motivation Theory and extended Theory of Planned Behavior. International Journal of Infectious Diseases, 99, 312-323. https://doi.org/10.1016/j.ijid.20 20.07.074

Priyadarsini dan Suresh (2020), Journal. Factors influencing the epidemiological characteristics of pandemic COVID 19: A TISM approach. International Journal of Healthcare Management ISSN: 2047-9700 (Print) 2047-9719 (Online)

https://www.tandfonline.com/lo i/yjhm20

Rosidin, U., Rahayuwati, L., \& Herawati, E. (2020). Perilaku dan Peran Tokoh Masyarakat dalam Pencegahan dan Penanggulangan Pandemi Covid -19 di Desa Jayaraga, Kabupaten Garut. Umbara, $\quad 5(1), \quad 42$. https: / /doi.org/10.24198/ umbara.v5i1.28187

Sastroasmoro, S., \& Ismael, S. (2014). Dasar Dasar Metodologi Penelitian Klinis. Sagung Seto.
Setiyaningsih, R., Tamtomo, D., \& Suryani, N. (2016). Health Belief Model: Determinantsof Hypertension Prevention BehaviorinAdults at Community Health Center, Sukoharjo, Central Java. Journal of Health Promotion and Behavior, 01(03), 160-170.

https: / /doi.org/10.26911/thejhp b.2016.01.03.03

Shereen, M. A., Khan, S., Kazmi, A., Bashir, N., \& Siddique, R. (2020). Covid-19 infection: Origin, transmission, and characteristics of human coronaviruses. Journal of Advanced Research, 24, 91-98. https: / /doi.org/ 10.1016/j.jare.2020.03.005

Sugiyono. (2014). Metode Penelitian Kuantitatif Kualitatif dan Kombinasi (Mixed Methods). Alfabeta.

Ummah, Kuntum Khaira, (2021). Jurnal Publikasi. Hubungan Persepsi Individu dengan Kepatuhan dalam Menerapkan Protokol Kesehatan Saat Pandemi Covid-19 pada Masyarakat Kabupaten Tanah Datar Tahun 2021. Fakultas Kesehatan Masyarakat Universitas Andalas Padang

Weiss, S. R., \& Navas-Martin, S. (2005). Coronavirus Pathogenesis and the Emerging Pathogen Severe Acute Respiratory Syndrome Coronavirus. Microbiology and Molecular Biology Reviews, 69(4), 635-664.

https://doi.org/10.1128/mmbr.6 9.4.635-664.2005

WHO. (2020a). termasuk penjangkauan dan kampanye, dalam konteks pandemi Covid-19 Panduan interim.

WHO. (2020b). WHO Coronavirus Disease (Covid-19) Dashboard. https: / /www.who.int/

WHO. (2021). WHO Coronavirus Disease.

WHO.Int.https: / covid19.who.int /table 
Wibowo, A. (2016). Kesehatan Masyarakat Indonesia. Raja Grafindo.

Wulandari, A., Rahman, F., Pujianti, N., Sari, A. R., Laily, N., Anggraini, L., Muddin, F. I., Ridwan, A. M., Anhar, V. Y., Azmiyannoor, M., \& Prasetio, D. B. (2020). Hubungan Karakteristik Individu dengan Pengetahuan tentang Pencegahan Coronavirus Disease 2019 pada Masyarakat di Kalimantan Selatan. Jurnal Kesehatan Masyarakat Indonesia, 15(1), $\quad 42$. https://doi.org/10.26714/jkmi.1

5.1.2020.42-46

Widyanto, Rio, Noorhidayah, Yeni Riza (2020). Journal. Faktor-Faktor yang Berhubungan dengan Kepatuhan Masyarakat dalam Penerapan Kebijakan Sosial dan Physical Distancing di Kecamatan Loksado Kabupaten Hulu Sungai Selatan Tahun 2020. Program Studi Kesehatan Masyarakat Fakultas Kesehatan Masyarakat Universitas Islam Kalimantan Muhammad Arsyad Al Banjari

Yanti, B., Wahyudi, E., Wahiduddin, W., Novika, R. G. H., Arina, Y. M. D., Martani, N. S., \& Nawan, N. (2020). Community Knowledge, Attitudes, and Behavior Towards Social Distancing Policy As Prevention Transmission of Covid19 in Indonesia. Jurnal Administrasi Kesehatan Indonesia, $8(2), \quad 4$. https://doi.org/10.20473/jaki.v8 i2.2020.4-14 . 